mental work on the crystallization of rock minerals in the laboratory is reviewed and Doelter's own observations on the precipitation of crystals in molten liquids are noted.

The question of the order of the eruption of different kinds of rocks at given centers of volcanic activity is treated in the sixth chapter. The diverse statements of petrographers as to the order in different regions are noted and the conclusion reached that there is no uniform order which obtains for all regions, but that the succession is highly complex.

The seventh chapter deals with inclusions in igneous rocks, their character and origin. Assimilation and corrosion are discussed in chapter eight. First the changes effected on minerals crystallized from magmas, and then the effects on rocks in contact with molten magmas. The laboratory production of rocks by experimental means is described in chapter nine, especially the researches of Fouqué and Michel-Léry, and those of Morezewicz.

In the tenth chapter the solidification of volcanic magmas is discussed with reference to the minerals produced under different conditions, and also with respect to the order of their separation. Laws affecting the crystallization of compounds from solutions are reviewed, the question of eutectic mixtures is considered, also the effect of undercooling, the melting point of minerals, and the influence of pressure on separation. The production of tuffs and bombs is also discussed. In the eleventh chapter contact metamorphism is described and its causes and processes discussed.

The crystalline schists are treated in one chapter of fifty-two pages. Various theories as to their origin are reviewed, chiefly those based on specific researches upon special regions or particular occurrences. It will be enough to note the captions under which the subject is treated: Eruptive Gneiss, Gneiss as Altered Granite, Diagenesis, Regional Metamorphism, The Chemical Composition of the Rocks, Alteration by Means of Water, Alteration by Means of High Temperature, Injection IIypothesis, Dynamic Metamorphism, Chemical Reactions in Solids, Plasticity of Rocks, Lateral Pressure, Connection between
Metamorphism and Dislocation, Law of the Change of Volume, Mineral Composition of Crystalline Schists, Structure and Texture of Schistose Rocks, Origin of Schistosity, Zones of Metamorphism, Objections to a General Application of Dynamic Metamorphism, Formation of Crystalline Śchists by Contact Metamorphism, Comparison of Contact Metamorphism and Dynamic Metamorphism.

The thirteenth chapter treats of sediments, their kinds and modes of formation. The major portion of the chapter is devoted to limestone and the formation of dolomite. The last chapter contains a discussion of the production of chemical precipitates, the deposition of rock salt, gypsum and anhydrite. The works of Bischof, van't Hoff and of Ochsenius are those chiefly cited.

J. P. IDDINGS

\section{The Origin and Structure of the Roxbury} Conglomerate. By George Rogers MansFIEld. Pp. 180, 7 pls. Cambridge, Mass., November, 1906. Bull. of the Museum of Comparative Zoology at Harvard College, Vol. XLIX. Geol. Series, Vol. VIII., No. 4. This paper, after a rather lengthy introduction, begins with a forty-five-page chapter on the origin of conglomerates, in which are discussed the various types of conglomerate. The discussion is thorough, and the results, drawn principally from the conclusions and opinions of previous writers in different countries, are tabulated. This digest is of general interest, and is a valuable contribution to the subject.

The remainder of the work deals principally with the three Carboniferous basins of Massachusetts and Rhode Island-the Boston Basin, which includes the Roxbury conglomerate; the Norfolk Basin, and the Narragansett Basin. The text is essentially a critical review of previous publications on these areas, especially of the Boston Basin, which has been studied in great detail by Professor W. O. Crosby. Professor Crosby's work in this region has extended over a period of at least thirty years, and no less than sixteen of his publications are included in the author's bibliography. In view of this fact it is noteworthy that, in the final paragraph of 
acknowledgments, Professor Crosby is not mentioned among those personally consulted, although he could have been reached by the author by a half hour's ride. This circumstance is in keeping with the general tone of the text, which leads one to believe that Crosby's work is to be proved faulty. Such a tone is unfortunate, since, with but three or four exceptions, the author is obliged to agree with all of Crosby's conclusions. Of the exceptions noted, one, on page 214 , is a resurrection of a controversy between Crosby and Burr, in which the former's contention that certain melaphyr areas were effusive, was disputed by the latter. Crosby's convincing answer to Burr's paper was published in the American Geologist (Vol. XXVII., p. 324, 1901), and, so far as known, has met with no reply; but still the present author believes that Burr's conclusions are in many instances correct. Regarding the other exceptions, on pages 206 and 220 , the author forms a different opinion, but in neither case proves himself correct nor Crosby wrong. In the second case the author states that he has not visited the outcrops which furnish Crosby's evidence. In his concluding chapter he states that, while Crosby attributed to the Roxbury conglomerate a marine origin, 'the evidence, largely negative and unsatisfactory, favors non-marine origin.' This and the conclusion that glaciers may have furnished material to torrents by which it was deposited either upon the land or in lakes are possible, though rather uncertain additions to the previous knowledge of the geology of the Boston Basin. The author has evidently accomplished a great deal of work in the time at his disposal, but it is unfortunate that so criticizing a tone should be employed by a young man in reviewing the work of so experienced and painstaking a geologist as Professor Crosby. It must, however, be exceedingly gratifying to the latter to see that his work, much of it done many years ago, when knowledge of geologic structure was far less advanced than at present, has stood so successfully all critical tests of recent years, and remains still the authority.

S. L. W.
A Text-book of Sanitary and Applied Chemistry. By E. H. S. BaIley. New York, The Macmillan Company. Price, $\$ 1.40$.

The author states that the object of this work is to furnish a text-book upon applied chemistry that is suitable for use by those students who have had a good high school course in general chemistry. Scattered material is also presented from government reports and other sources which has been added with the intention of making the book useful for reference. Part I. is entitled 'Sanitary Chemistry' and deals with: The Atmosphere, Fuels, Heating and Ventilation, Lighting, Water and its Purification, Sewage and its Disposal, Soap, Disinfectants, etc.

Under Part II. is considered the 'Chemistry of Foods.' Stress is laid upon the vitiated character of 'ground air,' and it is further noted how small is the attention given by the general public to the question of good ventilation, the reason being that the ills arising from a poor air supply are slow in making their appearance.

Under each heading there are experiments introduced with the view to fix in the student's mind the important points covered by the general text. In some cases, however, it is diffcult to see the value of these experiments. Thus, those under Water are qualitative only. Surely the results of a water analysis can scarcely be of service unless stated in a quantitative form. The field covered by the work is so very great that it is hardly to be expected that thoroughness can be attained in a book of 345 small pages. We find, for instance, Mineral Waters, Potable Waters, Drinking Water and Disease and the Purification of Water Supplies covered in twenty-three pages, while only seven are given to Sewage Disposal.

There are many things in the book which will interest the student reader, but he must remember that it is essentially elementary. Doubtless the author intended that it should be so considered.

$\mathrm{X}$.

\section{SCIENTIFIC JOURNALS AND ARTICLES}

The Psychological Clinic, a journal for the study and treatment of mental retardation and deviation, by Professor Lightner Witmer, 